ISSN: $1410-8917$

Jurnal Kimia

Sains \&

Aplikasi
Jurnal Kimia Sains dan Aplikasi Journal of Scientific and Applied Chemistry

Journal homepage: http://ejournal.undip.ac.id/index.php/ksa

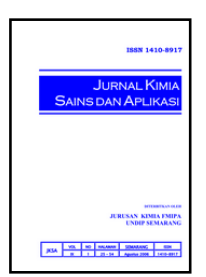

\title{
Fabrikasi Dye-Sensitized Solar Cell Menggunakan Fotosensitizer Ekstrak Bunga Rosela (Hibiscus sabdariffa L) dan Elektrolit Padat Berbasis PEG (Polyethylene Glycol))
}

\author{
Mustaqim $^{\mathrm{a}^{*}}$, Abdul Haris ${ }^{\mathrm{a}}$, Gunawan $^{\mathrm{a}}$ \\ a Analytical Chemistry Laboratory, Chemistry Department, Faculty of Sciences and Mathematics, Diponegoro University, Jalan Prof. \\ Soedarto, Tembalang, Semarang 50275 \\ * Corresponding author: a.haris@live.undip.ac.id
}

Article Info

Keywords:

Dye-Sensitized Solar

Cell, Rosela flower

(Hibiscus sabdariffa L),

Solid electrolyte
Kata kunci:

Dye-Sensitized Solar

Cell, Bunga Rosela

(Hibiscus sabdariffa

L), Elektrolit Padat

\section{Abstract}

Dye sentisized solar cell (DSSC) was fabricated using natural dye of rosella extract and PEG (polyethylene glycol) based solid electrolyte containing a redox couple of $\mathrm{I}^{-} / \mathrm{I}_{3}^{-}$. Dyesentisized solar cell was constructed as a sandwich structure with a photoelectrode of $\mathrm{TiO}_{2}$ deposited on transparent conductive oxide (TCO) and graphite as a counter electrode. Rosella extract, maserated in a mixture of methanol, acetic acid and water for 24 hours, was used for immersion of photoelectrode $\mathrm{TiO}_{2}$ for 1 hour and 24 hours. Dye was characterized using FT-IR and UV-Vis spectrophotometers, while $\mathrm{TiO}_{2}$ was characterized using XRD and SEM. The performance of the dye sentisized solar cell was examined under natural sunlight irradiation for 1 hour on 00:15-01:15 pm at atmosphere temperature of $39^{\circ} \mathrm{C}$. Characterization results showed that $\mathrm{TiO}_{2}$ thin layer had anatase phases and porous surfaces with a crystal size ca. $41.56 \mathrm{~nm}$. UV-Vis spectra showed that the dye had a maximum absorption at $530 \mathrm{~nm}$, while FT-IR spectra assigned the presence of carbonyl and hydroxyl groups of the dye. The fabricated solar cell had VOC (open circuit potential) of 0.124 and $0.127 \mathrm{~V}, \mathrm{I}_{\mathrm{sc}}$ (short cut current) of 0.084 and 1.275 $\mathrm{mA}$, and also efficiency of $0.00098 \%$ and $0.01883 \%$ for $\mathrm{TiO}_{2}$ electrode immersion for 1 hour and 24 hours, respectively.

\section{Abstrak}

Telah dibuat Dye-Sensitized Solar Cell (DSSC) menggunakan dye alami ekstrak bunga Rosela dan elektrolit padat berbasis PEG yang mengandung pasangan redoks $\mathrm{I}^{-} / \mathrm{I}_{3}{ }^{-}$. DyeSensitized Solar Cell dikonstruksi dengan struktur sandwich menggunakan fotoelektrode $\mathrm{TiO}_{2}$ yang dideposisi pada kaca Transparent Conductive Oxide (TCO) dengan elektrode lawan grafit. Dye ekstrak bunga rosela dimaserasi dalam campuran metanol, asam asetat dan air selama 24 jam dan digunakan untuk perendaman fotoelektroda $\mathrm{TiO}_{2}$ selama 1 jam dan 24 jam. Dye dikarakterisasi menggunakan FT-IR dan UV-Vis dan $\mathrm{TiO}_{2}$ menggunakan X-RD dan SEM. Kinerja sel surya diuji di bawah sinar matahari selama 1 jam pada jam 12:15-13:15 dengan suhu atmosfir $39^{\circ} \mathrm{C}$. Spektra UV-Vis dan FT-IR larutan dye menunjukkan adanya kandungan antosianin pada panjang gelombang maksimum $530 \mathrm{~nm}$ dan diperkuat dengan munculnya gugus hidroksil, benzena dan karbonil pada serapan inframerah. Hasil karakterisasi XRD dan SEM menunjukkan $\mathrm{TiO}_{2}$ memiliki fase kristalin anatase dengan ukuran kristal sebesar 41,56 nm dan morfologi permukaan dengan ukuran rongga sekitar 94,11nm dan ketebalan penampang lintang sekitar 39,05. Dye-Sensitized Solar Cell yang dibuat menghasilkan potensial rangkaian terbuka (VOC) sebesar $0,124 \mathrm{~V}$ dan $0,127 \mathrm{~V}$, arus rangkaian pendek (ISC) 0,084 mA dan 1,275 mA, serta 


\section{Pendahuluan}

Dye Sensitized Solar Cell (DSSC) merupakan salah satu piranti fotovoltase yang menarik perhatian para peneliti beberapa tahun ini karena komponennya tidak memerlukan biaya mahal. Komponen tersebut antara lain logam oksida nanokristal, molekul zat warna (dye), dan elektrolit yang mengandung pasangan redoks $\mathrm{I}^{-} / \mathrm{I}_{3}{ }^{-}$. Ketiga komponen ini memiliki peranan penting dalam menghasilkan efisiensi konversi energi sistem DSSC [1]. Oksida logam nanokristal yang banyak digunakan sebagai semikonduktor pada pembuatan elektroda kerja DSSC yaitu $\mathrm{TiO}_{2}$. Oksida logam ini selain relatif murah, juga lebih stabil (tahan terhadap korosi) dibanding oksida logam lain yang juga bisa digunakan seperti $\mathrm{ZnO}$ dan $\mathrm{WO}_{3}$ [2]. Struktur dan ketebalan lapisan $\mathrm{TiO}_{2}$ dalam pembuatan elektroda kerja juga memberikan pengaruh pada efisiensi konversi energi. Hal ini berkaitan dengan jumlah molekul dye yang teradsorpsi ke dalam lapisan $\mathrm{TiO}_{2}[3,4]$.

Pada awalnya, molekul dye yang digunakan sebagai sensitizer dalam sistem DSSC adalah zat warna sintetik seperti kompleks ruthenium. Penelitian yang menggunakan turunan kompleks ruthenium diantaranya cis-di(thiocyanato)-N,N-bis(2,2' bypyridil-4,4'dicarboxylic acid) ruthenium (II) [5]. Penggunaan kompleks ruthenium $\mathrm{RuL}_{3}$ (L:2,2'bipyridyl-4,4-dicarboxylate) menghasilkan efisiensi sebesar $10,6 \%$ [6], tetapi selain harganya mahal juga dapat mencemari lingkungan. Oleh karena itu, penelitian DSSC dialihkan menggunakan zat warna . dalam ekstrak tanaman, seperti senyawa antosianin dari kol merah [7], buah delima [8] dan penelitian menggunakan ekstrak bunga rosela dalam pembuatan sel surya menghasilkan efisisensi sebesar 0,05\% [9]. Komponen ketiga yang berperan dalam menentukan efisiensi DSSC yaitu elektrolit. Elektrolit ini mengandung pasangan redoks yang dapat mereduksi dye teroksidasi dan berfungsi sebagai pembawa elektron antar elektroda dalam DSSC. Dengan demikian, suatu elektrolit mengandung pasangan redoks yang sesuai berperan penting dalam penentuan efisiensi DSSC. Pasangan $\mathrm{I}^{-} / \mathrm{I}_{3}{ }^{-}$sejauh ini merupakan pasangan redoks terbaik untuk mereduksi dye secara efektif [10]. Pasangan redoks $\mathrm{I}^{-} / \mathrm{I}_{3}^{-}$umumnya dilarutkan dalam pelarut organik yang juga berperan sebagai medium elektrolit. Dalam hal ini, digunakan pelarut organik seperti asetonitril sebagai pelarut pasangan redoks $\mathrm{I}^{-} / \mathrm{I}_{3}{ }^{-}$ - Namun demikian, penggunaan elektrolit cair mempunyai kelemahan yaitu kebocoran serta penguapan pelarut sehingga stabilitas dan daya tahan DSSC menjadi rendah serta menurunkan nilai efisiensi. Oleh karena itu, perlu dilakukan penelitian untuk memperbaiki fungsi elektrolit yang merupakan salah satu faktor penentu nilai efisiensi konversi energi sistem DSSC.
Beberapa tahun ini telah banyak dikembangkan DSSC menggunakan elektrolit padat atau gel berbasis matriks polimer untuk menggantikan elektrolit cair. dengan menggabungkan penggunaan elektrolit padat berbasis gel polimer polyethylene glycol (PEG) dengan dye alami ekstrak kol merah menghasilkan efisiensi $0,023 \%$ dan $0,055 \%$ masing-masing untuk waktu perendaman 1 jam dan 24 jam [7]. Selain itu juga, efisiensi konversi energi DSSC padat yang cukup besar (3,64 \%) telah dicapai menggunakan PEG dengan bobot molekul rendah $(1000 \mathrm{~g} / \mathrm{mol})$ menghasilkan penetrasi elektrolit yang lebih efektif ke lapisan nanopori $\mathrm{TiO}_{2}$ sehingga kontak antarmuka yang dihasilkan lebih baik [11], dan menggunakan PEG, polymethyl metacrylate (PMMA), dan polyacrylonitrile (PAN) masing-masing menghasilkan efisiensi 0,195\%, 0,132\%, 0,196\% [5].

Dalam penelitian ini digunakan elektrolit padat berbasis polimer PEG dengan dye bunga rosela dan ditentukan efisiensi konversi enenrgi DSSC yang telah dihasilkan.

\section{Metode Penelitian}

Bahan- bahan yang digunakan dalam penelitian ini meliputi Kaca Transparent Conductive Oxide (TCO) (Sigma Aldrich), serbuk $\mathrm{TiO}_{2}$ (Merck), metanol, asam asetat, polyvinyl alcohol, potasium iodida, $\operatorname{Iod}\left(\mathrm{I}_{2}\right)$ asetonitril, kloroform, polyethylene glycol BM-4000, Bunga Rosela, serbuk grafit.

Peralatan yang digunakan antara lain multimeter, potensiometer, Magnetic Stirrer Hotplate, Furnace, peralatan gelas, mortar porselin, Scotch tape,Spektrofotometri UV-Vis PG Instruments Limited Model T60U , XRD Shimadzu 7000, SEM jeol jsm-6360 LA, dan FTIR Thermo Nicolet Avatar 360.

\section{Pembuatan Pasta $\mathrm{TiO}_{2}$}

Polivinilalkohol (PVA) sebanyak 0,5 gram ditambahkan ke dalam 4,5 mL air, kemudian diaduk pada temperatur $80^{\circ} \mathrm{C}$. Suspensi ini berfungsi sebagai pengikat dalam pembuatan pasta. Langkah selanjutnya, penambahan suspensi tersebut pada bubuk $\mathrm{TiO}_{2}$ sebanyak kurang lebih 4,5 gam. Kemudian digerus dengan mortar sampai terbentuk pasta yang baik untuk dilapiskan. Derajad kekentalan pasta yang optimal didapatkan dengan mengatur banyaknya pengikat dan bila diperlukan dapat ditambah air pada campuran pengikat dan bubuk $\mathrm{TiO}_{2}$.

\section{Ekstraksi Dye Ekstrak Bunga Rosela}

Sebanyak 1,5 gram bunga rosela direndam ke dalam metanol:asam asetat:air (25:4:21 perbandingan volume) sebanyak $10 \mathrm{~mL}$. Kemudian dimaserasi selama 24 jam [12]. 


\section{Pembuatan Elektrolit-Polimer}

Sebanyak 0,8 gram potassium iodida (KI) dilarutkan ke dalam $10 \mathrm{~mL}$ asetonitril kemudian diaduk, ditambahkan 0,127 gram iod $\left(\mathrm{I}_{2}\right)$ ke dalam larutan tersebut kemudian diaduk. Sebanyak 7 gram PEG dilarutkan dengan $25 \mathrm{~mL}$ kloroform hingga membentuk gel, kemudian dimasukkan 5 tetes larutan yang telah dibuat sebelumnya.

\section{Pembuatan Counter electrode}

Sebagai sumber karbon digunakan grafit. Grafit dilapiskan pada bagian penghantar kaca TCO. Kemudian dipanaskan pada temperatur $450^{\circ} \mathrm{C}$ selama 10 menit, setelah dingin digunakan sebagai counter electrode.

\section{Pembuatan dan Karakterisasi Sel Surya}

Elektroda $\mathrm{TiO}_{2}$ dibuat dengan melapiskan pasta $\mathrm{TiO}_{2}$ pada kaca TCO dengan ukuran luasan 2 x 1,5 cm2, kemudian dua buah elektroda ini direndam dalam larutan dye masing-masing selama 1 jam dan 24 jam. Kemudian elektrolit polimer dilapiskan pada elektroda $\mathrm{TiO}_{2}$ yang telah disensitisasi dengan dye dan ditutup dengan counter electrode menjadi struktur sandwich. Sel surya tersebut kemudian diukur arus dan tegangannya dengan multimeter dalam keadaan disinar cahaya matahari. Karakterisasi komponen pembuatan sel surya meliputi analisis menggunakan Spektrofotometri UVVis dan FTIR pada larutan dye ekstrak bunga rosela untuk mengetahui panjang gelombang maksimum dan serapan gugus fungsional yang ada. Analisis SEM dan XRD pada lapis tipis $\mathrm{TiO}_{2}$ yang dihasilkan untuk mengetahui morfologi serta fase kristal $\mathrm{TiO}_{2}$.

\section{Hasil dan Pembahasan}

Karakterisasi Lapis Tipis $\mathrm{TiO}_{2}$ dengan Metode XRD dan SEM

Analisis dengan metode difraksi sinar-X dilakukan untuk menentukan fase dan ukuran kristal lapis tipis $\mathrm{TiO}_{2}$ yang dihasilkan pada photoelectrode. Pola difraksi sinar-X lapis tipis $\mathrm{TiO}_{2}$ ditunjukkan pada gambar 1. Pola difraksi yang dihasilkan menunjukkan derajat kristalisasi $\mathrm{TiO}_{2}$ yang cukup tinggi dengan adanya puncak tajam dan intensitas yang besar. Data difraktogram lapis tipis $\mathrm{TiO}_{2}$ menunjukkan adanya tiga puncak pada $2 \theta$ yaitu 29,$57 ; 44,26$; dan 56,55 serta jarak

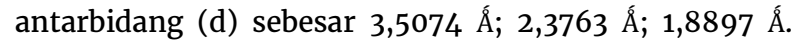
Hasil analisis ini menunjukkan bahwa fase kristal lapis tipis $\mathrm{TiO}_{2}$ yang dihasilkan adalah anatase. Hasil ini sesuai dengan data JCPDS anatase 12-1272 puncak kristalisasi dihasilkan pada jarak antarbidang 3,52 Á; 2,38 ̊́; 1,89 Á. Fase kristal $\mathrm{TiO}_{2}$ yang efektif digunakan sebagai photoelectrode pada sel surya adalah anatase. Hal ini disebabkan oleh transport elektron dalam kristal anatase relatif lebih cepat karena kristal anatase mempunyai derajat kristalinitas yang baik. Berdasarkan perhitungan menggunakan persamaan Scherrer diperoleh ukuran kristal anatase lapis tipis $\mathrm{TiO}_{2}$ sebesar 41,56 nm. Selain itu, luas permukaan kristal anatase yang cukup luas juga menyebabkan jumlah molekul dye yang teradsorpsi lebih banyak. Semakin banyak molekul dye yang teradsorpsi, semakin banyak pula elektron yang tereksitasi dan terinjeksi pada substrat kaca TCO.

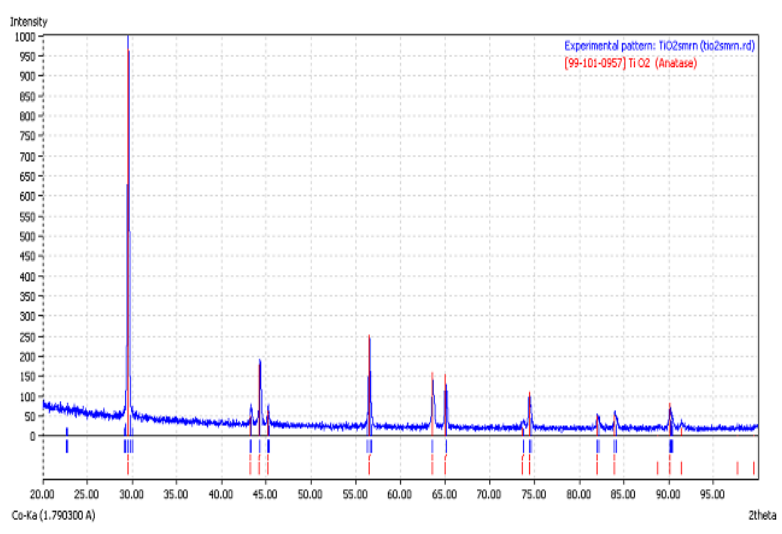

Gambar 1. Difraktogram Lapis Tipis $\mathrm{TiO}_{2}$ pada Substrat Kaca

Analisis menggunakan SEM dilakukan untuk mengetahui karakteristik morfologi dan penampang lintang lapis tipis $\mathrm{TiO}_{2}$. Hasil scanning lapis tipis $\mathrm{TiO}_{2}$ disajikan pada gambar 2. Berdasarkan hasil scanning dapat diketahui bahwa morfologi permukaan lapis tipis $\mathrm{TiO}_{2}$ berongga-rongga dengan ukuran rongga 94,11 nm. Rongga pada permukaan lapis tipis $\mathrm{TiO}_{2}$ berperan untuk mengadsorpsi molekul-molekul dye antosianin. Jumlah dan luas rongga ini mempengaruhi efektivitas adsorpsi molekul-molekul dye antosianin ke dalam lapis tipis $\mathrm{TiO}_{2}[13]$

a.

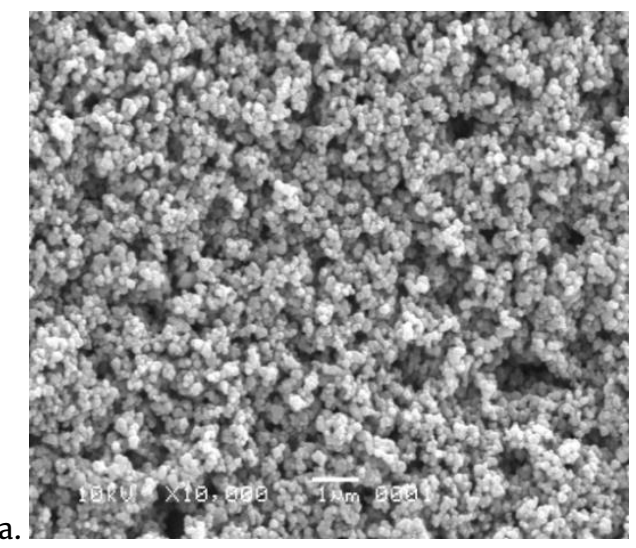

b.

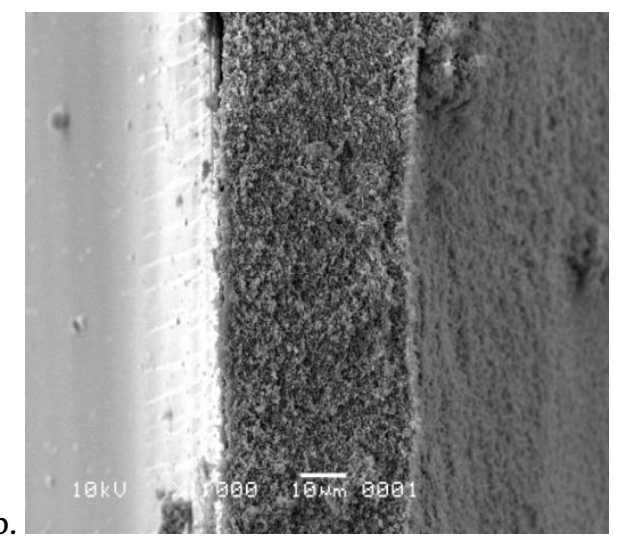

Gambar 2. a. Morfologi permukaan lapis tipis $\mathrm{TiO}_{2}$ perbesaran 10.000 kali. b. Penampang lintang lapis tipis $\mathrm{TiO}_{2}$ perbesaran 10.000 kali 
Penampang lintang lapis tipis $\mathrm{TiO}_{2}$ hasil scanning SEM mempunyai ketebalan sebesar 39,05 $\mu \mathrm{m}$. Ketebalan lapis tipis $\mathrm{TiO}_{2}$ mempengaruhi aliran elektron karena elektron yang terinjeksi ke dalam lapis tipis $\mathrm{TiO}_{2}$ melewati sejumlah besar partikel koloid. Semakin besar ketebalan lapis tipis $\mathrm{TiO}_{2}$ akan memperbesar kemungkinan rekombinasi elektron dan dapat menurunkan efisiensi sel surya [3].

\section{Analisis Larutan Zat Warna Menggunakan} Spektrofotometri UV-Vis dan FTIR

Ekstrak bunga rosela yang diperoleh dianalisis dengan Spektrofotometri UV-Vis untuk mengetahui panjang gelombang maksimum larutan dye tersebut. Spektra UV-Vis ekstrak rosela hasil analisis disajikan pada gambar 3. Spektra UV-Vis larutan dye menunjukkan bahwa ekstrak bunga rosela menyerap foton pada panjang gelombang maksimum $530 \mathrm{~nm}$.

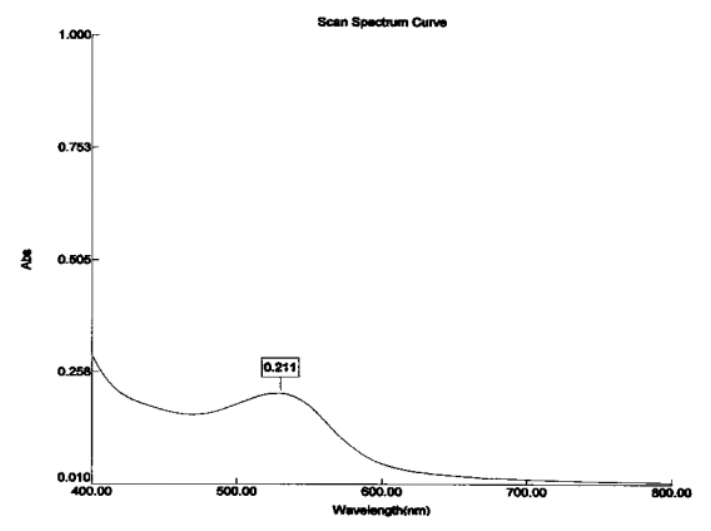

Gambar 3. Hasil UV-Vis ekstrak rosela

Hasil ini menunjukkan bahwa pigmen antosianin ekstrak bunga rosela menyerap cahaya pada daerah panjang gelombang sinar tampak dan dapat digunakan sebagai dye dalam sistem DSSC. Analisis dengan spektroskopi inframerah dilakukan untuk mengetahui gugus-gugus fungsional yang ada pada zat warna ekstrak bunga rosela sehingga dapat diperkirakan interaksi antara zat warna dengan lapis tipis $\mathrm{TiO}_{2}$. Zat warna yang dapat digunakan sebagai sensitizer adalah zat warna yang dapat teradsorpsi dan memiliki gugus fungsional yang dapat berikatan dengan permukaan $\mathrm{TiO}_{2}[14]$.

Spektra serapan inframerah zat warna ekstrak bunga rosela pada gambar 4 menunjukkan adanya pita tajam pada daerah $3560,73 \mathrm{~cm}^{-1}$ yang menunjukkan adanya gugus hidroksi $(\mathrm{OH})$ yang dapat membentuk suatu ikatan hidrogen. Pita tajam yang lain ditunjukkan pada daerah $1718,34 \mathrm{~cm}^{-1}$ yang menandakan bahwa dalam ekstrak bunga rosela mengandung gugus karbonil. Pita serapan gugus karbonil ini muncul karena adanya kesetimbangan senyawa antosianin yang berada dalam bentuk sianidin quinoidal. Serapan pada daerah $1015,88 \mathrm{~cm}^{-1}$ diidentifikasi sebagai gugus C-O. Serapan pada daerah $1638,77 \mathrm{~cm}^{-1}$ menunjukkan adanya gugus $\mathrm{C}=\mathrm{C}$, sedangkan serapan tajam pada daerah $587,83 \mathrm{~cm}^{-1}$ menunjukkan adanya gugus benzena.

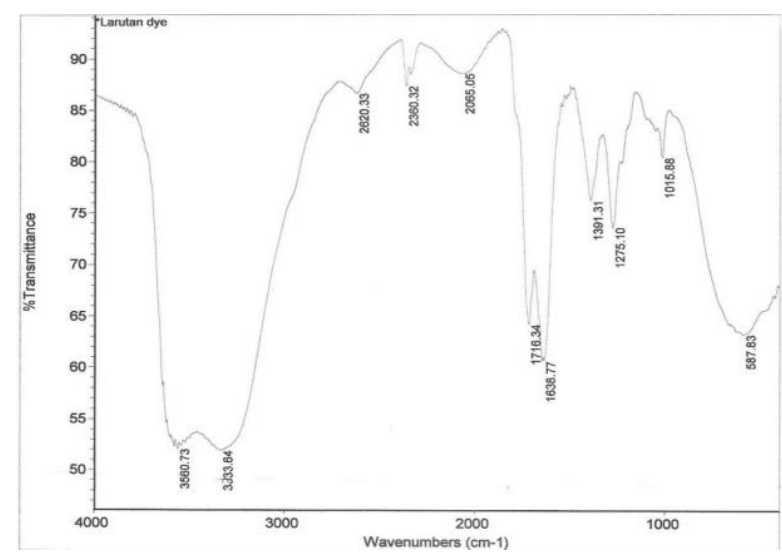

Gambar 4. Spektra serapan inframerah zat warna

\section{Elektrolit-Polimer Polyethylene Glycol (PEG)}

Elektrolit padat berbasis PEG (polyethylene glycol) mengandung pasangan redoks $\mathrm{I}^{-} / \mathrm{I}_{3}^{-}$yang telah dibuat berwarna kuning kecoklatan menunjukkan iodine larut sempurna dalam PEG. Dalam elektrolit padat ini, PEG berperan sebagai medium pasangan redoks $\mathrm{I}^{-} / \mathrm{I}_{3}{ }^{-}$karena PEG mampu menjerat anion $\mathrm{I}^{-} / \mathrm{I}_{3}{ }^{-}$. Spesies $\mathrm{I}_{3}{ }^{-}$terbentuk melalui reaksi antara I- dan I2 sebagai berikut:

$\mathrm{I}^{-}+\mathrm{I}_{2} \rightarrow \mathrm{I}_{3}^{-}$

$2 \mathrm{Dye}^{+}+3 \mathrm{I}^{-} \rightarrow 2 \mathrm{Dye}+\mathrm{I}_{3}$

$\mathrm{I}_{3}{ }^{-}+2 \mathrm{e}-($ counter electrode $) \rightarrow 3 \mathrm{I}^{-}$

Pasangan redoks $\mathrm{I}^{-} / \mathrm{I}_{3}^{-}$berperan sebagai carrier dan transport muatan sehingga memungkinkan siklus elektron dan regenerasi molekul dye dalam DSSC yang ditunjukkan oleh reaksi di atas. Penggunaaan PEG dalam penenlitian ini sebagai medium pasangan redoks $\mathrm{I}^{-} / \mathrm{I}_{3}{ }^{-}$ telah berhasil meningkatkan efisiensi DSSC hasil penelitian sebelumnya yang menggunakan elektrolit cair untuk dye yang sama. Hal ini dapat terjadi karena elektrolit-polimer PEG mempunyai fase padat sehingga mampu mencegah penguapan pasangan redoks $\mathrm{I}^{-} / \mathrm{I}_{3}{ }^{-}$ dan siklus elektron serta regenerasi molekul dye berlangsung dengan baik.

\section{Karakteristik Arus-Tegangan DSSC}

Pengukuran arus dan tegangan pada sel surya yang menggunakan elektrolit-polimer dan ekstrak bunga rosela sebagai zat warna dengan waktu perendaman photoelectrode $\mathrm{TiO}_{2}$ dalam zat warna selama 1 jam dan 24 jam. Arus dan tegangan yang diperoleh untuk waktu perendaman selama 24 jam lebih besar daripada perendaman selama 1 jam. Hal ini disebabkan oleh semakin lama waktu perendaman menyebabkan semakin banyak jumlah molekul antosianin yang teradsorpsi pada permukaan lapis tipis $\mathrm{TiO}_{2}$ sehingga penyerapan foton juga lebih besar. Semakin banyak foton yang diserap menyebabkan jumlah molekul dye tereksitasi juga semakin banyak dan jumlah elektron yang terinjeksi ke dalam lapis tipis $\mathrm{TiO}_{2}$ pun semakin banyak. Kurva arus-tegangan dengan variasi waktu perendaman 1 jam dan 24 jam disajikan dalam gambar 5. 


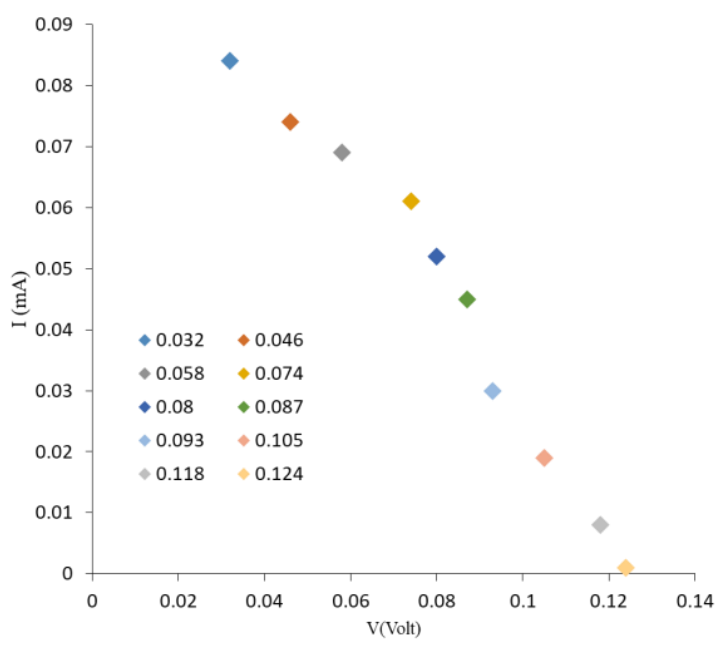

a.

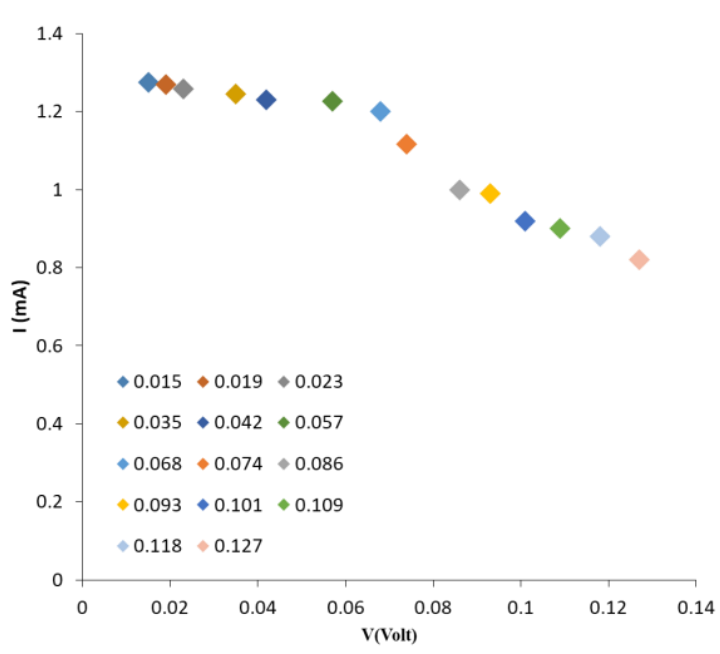

Gambar 5. Kurva Arus dan Tegangan DSSC (a) 1 jam (b) 24 jam

Berdasarkan hasil pengukuran nilai arus dan tegangan yang telah dibuat dalam bentuk kurva I-V, diperoleh parameter-parameter keluaran sel surya seperti dirangkum dalam tabel 1 . Tegangan rangkaian terbuka (VOC) yang dihasilkan sebesar 0,124 V dan $0,127 \mathrm{~V}$, masing-masing untuk waktu perendaman 1 jam dan 24 jam. Sedangkan, arus rangkaian pendek (ISC) yang dihasilkan sebesar 0,084 mA dan 1,275 mA. Arus yang dihasilkan ini relatif kecil disebabkan oleh besarnya nilai hambatan lapis tipis $\mathrm{TiO}_{2}$ besar yang mencapai orde kiloOhm $(k \Omega)$ [7]. Selain itu juga, terjadinya rekombinasi elektron yang tidak diinginkan antara elektron yang telah terinjeksi dengan zat warna teroksidasi elektrolit redoks teroksidasi $\left(\mathrm{I}_{3}^{-}\right)$ menyebabkan arus keluaran sel surya yang kecil.

Reaksi rekombinasi elektron yang terjadi yaitu:

$\mathrm{Dye}^{+}+\mathrm{e}-\left(\mathrm{TiO}_{2}\right) \rightarrow$ Dye $+\mathrm{TiO}_{2}$

$\mathrm{I}_{3}^{-}+2 \mathrm{e}-\left(\mathrm{TiO}_{2}\right) \rightarrow 3 \mathrm{I}^{-}+\mathrm{TiO}_{2}$
Tabel 1: Parameter keluaran sel surya

\begin{tabular}{ccc}
\hline $\begin{array}{c}\text { Karakterisasi I- } \\
\text { V }\end{array}$ & $\begin{array}{c}\text { Perendaman 24 } \\
\text { jam }\end{array}$ & $\begin{array}{c}\text { Perendaman } 1 \\
\text { jam }\end{array}$ \\
\hline VOC (V) & 0,127 & 0,124 \\
ISC (A) & $1,275 \times 10^{-3}$ & $0,084 \times 10^{-3}$ \\
VMPP (V) & 0,046 & 0,071 \\
IMPP (A) & $1,275 \times 10^{-3}$ & $0,059 \times 10^{-3}$ \\
FF & 0,349 & 0,402 \\
PMAX (W) & $5,65 \times 10^{-5}$ & $2,94 \times 10^{-6}$ \\
$\eta(\%)$ & $0,01883 \%$ & $0,00098 \%$ \\
\hline
\end{tabular}

Efisiensi yang dihasilkan sel surya menggunakan elektrolit-polimer PEG sebesar 0,00098 \% dan 0,01883 $\%$, masing-masing untuk waktu perendaman 1 jam dan 24 jam. Elektrolit polimer mempunyai kestabilan yang lebih baik dibanding elektrolit cair karena elektrolit cair yang mudah sekali menguap. Padahal, dalam sistem DSSC elektrolit yang mengandung pasangan redoks $\mathrm{I}^{-}$ $/ \mathrm{I}_{3}{ }^{-}$berperan penting dalam regenerasi electron yang disumbangkan kepada molekul dye teroksidasi untuk kembali ke keadaan ground state. Semakin stabil elektrolit yang digunakan, regenerasi elektron juga berlangsung dengan baik yang secara keseluruhan menentukan efisiensi yang dihasilkan sel surya.

\section{Kesimpulan}

Prototype DSSC dapat dibuat dengan ekstrak bunga rosela sebagai zat warna peka cahaya (sensitizer) yang dikombinasikan dengan elektrolit padat berbasis PEG. Penggunaan elektrolit polimer menghasilkan efisiensi sebesar $0,00098 \%$ dan $0,01883 \%$, masing-masing untuk waktu perendaman dye 1 jam dan 24 jam.

\section{Daftar Pustaka}

[1] M. Grätzel, A. J. McEvoy, Principles and applications of dye sensitized nanocrystalline solar cells (DSC), Asian Journal on Energy and Environment, 5, 3, (2004) 197-210

[2] Jarnuzi Gunlazuardi, Fotokatalisis pada Permukaan TiO2: Aspek Fundamental dan Aplikasinya, Seminar Nasional Kimia Fisika II, (2001).

[3] K. Kalyanasundaram, M. Grätzel, Applications of functionalized transition metal complexes in photonic and optoelectronic devices, Coordination Chemistry Reviews, 177, 1, (1998) 347-414 https://doi.org/10.1016/S0010-8545(98)00189-1

[4] Miao Wang, Xurui Xiao, Xiaowen Zhou, Xueping Li, Yuan Lin, Investigation of PEO-imidazole ionic liquid oligomer electrolytes for dye-sensitized solar cells, Solar Energy Materials and Solar Cells, 91, 9, (2007) https://doi.org/10.1016/j.solmat.2007.01.009

[5] Mi-Ra Kim, Sung-Ho Jin, Sung-Hae Park, HyunJeong Lee, Eun-Hee Kang, Jin-Kook Lee, Photovoltaic Properties and Preparations of DyeSensitized Solar Cells Using Solid-State Polymer Electrolytes, Molecular Crystals and Liquid Crystals, 444, $1, \quad$ (2006) 233-239 http://dx.doi.org/10.1080/15421400500365037 
[6] Michael Grätzel, Conversion of sunlight to electric power by nanocrystalline dye-sensitized solar cells, Journal of Photochemistry and Photobiology A: Chemistry, 164, 1, (2004) 3-14 https://doi.org/10.1016/j.jphotochem.2004.02.023

[7] Akhiruddin Maddu, Mahfuddin Zuhri, Irmansyah Irmansyah, Penggunaan Ekstrak Antosianin Kol Merah Sebagai Fotosensitizer pada Sel Surya TiO2 Nanokristal Tersensitisasi Dye, Makara, 11, 2, (2009) $78-84$

[8] P. M. Sirimanne, M. K. I. Senevirathna, E. V. A. Premalal, P. K. D. D. P. Pitigala, V. Sivakumar, K. Tennakone, Utilization of natural pigment extracted from pomegranate fruits as sensitizer in solid-state solar cells, Journal of Photochemistry and Photobiology A: Chemistry, 177, 2, (2006) 324-327 https://doi.org/10.1016/j.jphotochem.2005.07.003

[9] Khwanchit Wongcharee, Vissanu Meeyoo, Sumaeth Chavadej, Dye-sensitized solar cell using natural dyes extracted from rosella and blue pea flowers, Solar Energy Materials and Solar Cells, 91, 7, (2007) 566-571 https://doi.org/10.1016/j.solmat.2006.11.005

[10] Brian A. Gregg, Excitonic Solar Cells, The Journal of Physical Chemistry B, 107, 20, (2003) 4688-4698 10.1021/jp022507x

[11] Moon-Sung Kang, Jong Hak Kim, Jongok Won, Yong Soo Kang, Dye-sensitized solar cells based on crosslinked poly(ethylene glycol) electrolytes, Journal of Photochemistry and Photobiology A: Chemistry, 183, 1, (2006) 15-21 https://doi.org/10.1016/j.jphotochem.2006.02.013

[12] Wilman Septina, D Fajarisandi, M Aditia, Pembuatan Prototipe Solar Cell Murah dengan Bahan Organik-Inorganik (Dye-sensitized Solar Cell), in: Laporan Akhir Penelitian Bidang Energi, Penghargaan PT. Rekayasa Industri, 2007.

[13] Jae-Wook Lee, Kyung-June Hwang, Wang-Geun Shim, Kyung-Hee Park, Hal-Bon Gu, Kyu-Hyuk Kwun, Energetic surface heterogeneity of nanocrystalline TiO2 films for dye-sensitized solar cells, Korean Journal of Chemical Engineering, 24, 5, (2007) 847-850 10.1007/s11814-007-0052-4

[14] Greg P. Smestad, Michael Gratzel, Demonstrating Electron Transfer and Nanotechnology: A Natural Dye-Sensitized Nanocrystalline Energy Converter, Journal of Chemical Education, 75, 6, (1998) 752 10.1021/edo75p752 